\title{
BENTUK PENYIMPANGAN PRINSIP KESANTUNAN BERBAHASA DALAM DISKUSI
}

\author{
Nirmalasari Makmur, H. Rustam Efendy Rasyid, dan H. Aminuddin Mamma \\ Universitas Muhammadiyah Sidenreng Rappang \\ Jl. Angkatan 45 No 1A Lautang Salo Rappang, Pancarijang, Sidenreng Rappang \\ makmurnirmalasari@yahoo.com
}

\begin{abstract}
Abstrak: Bentuk Penyimpangan Prinsip Kesantunan Berbahasa dalam Diskusi. Penelitian ini bertujuan untuk mendeskripsikan penyimpangan prinsip kesantunan berbahasa yang terjadi dalam kegiatan diskusi pada siswa kelas VII SMP Negeri 1 Panca Rijang. Metode yang digunakan dalam penelitian ini adalah metode deskriptif kualitatif. Teknik yang digunakan dalam mengumpulkan data menggunakan teknik simak, teknik rekam dan teknik catat. Analisis data menggunakan metode padan pragmatik. Hasil penelitian menunjukkan bahwa penyimpangan prinsip kesantunan berbahasa terdiri dari enam maksim, meliputi maksim kebijaksanaan, kesimpatian, penghargaan, kedermawanan, kesederhanaan dan permufakatan. Di antara maksim-maksim kesantunan, maksim yang paling banyak disimpangkan dalam hal pemilihan kata dan cara berdiskusi yang santun adalah maksim penghargaan.
\end{abstract}

Kata kunci: diskusi, penyimpanngan, prinsip kesantunan berbahasa

\begin{abstract}
The deviations Principle of Language Politeness in Discussion. This study aims to describe the deviations and compliance with the principle of politeness in language that occurs in discussion in class VII students of SMP Negeri 1 Pancarijang. The method used in this research is descriptive qualitative method. The technique used in collecting data uses listening techniques, record techniques and note taking techniques. Data analysis uses the pragmatic equivalent method. Data deviations from the politeness principle of language consists of six maxims, including maxims of wisdom, sympathy, appreciation, generosity, simplicity and consensus. Among the maxim of politeness, the maxim that is most distorted in terms of word choice and polite manner of discussion is the maxim of appreciation. Meanwhile, the maxim that is the most followed in terms of word choice and polite discussion is the maxim of wisdom.
\end{abstract}

Keyword: discussion, principle of language politenss, the deviations

\section{PENDAHULUAN}

Bahasa merupakan sebuah sarana yang digunakan manusia untuk berkomunikasi. Sesuai dengan fungsinya, bahasa memiliki peran sebagai penyampai pesan antara manusia satu dengan lainnya. Bahasa adalah sistem lambang bunyi yang arbitrer, yang dipergunakan oleh para anggota suatu masyarakat untuk bekerja sama, berinteraksi dan mengidentifikasikan diri (Kridalaksana, 1993). Dalam kehidupan sehari-hari, manusia pasti menggunakan bahasa untuk berinteraksi satu sama lain. Fungsi bahasa adalah alat untuk berinteraksi atau sebagai alat komunikasi, dalam arti bahasa digunakan untuk menyampaikan informasi, perasaan, gagasan, ataupun konsep (Chaer \& Agustina, 2004).

Dalam berinteraksi, diperlukan aturanaturan yang mengatur penutur dan lawan tutur agar nantinya dapat terjalin komunikasi yang baik diantara keduanya. membagi prinsip kesantunan menjadi enam, yakni maksim kebijaksanaan, maksim kedermawanan, maksim penghargaan, maksim kesederhanaan, maksim permufakatan, dan maksim (Leech, 1993). 
Dalam berbahasa, manusia perlu memperhatikan adanya kesantunan berbahasa ketika berkomunikasi dengan manusia lainnya. Hal itu bertujuan agar manusia bisa menggunakan bahasa yang santun dan tidak melakukan kesalahan dalam berbahasa. Sebuah tuturan dikatakan santun atau tidak,sangat tergantung pada ukuran kesantunan masyarakat penutur bahasa yang dipakai. Tuturan dalam bahasa Indonesia secara umum sudah dianggap santun jika penutur menggunakan kata-kata yang santun, tuturannya tidak mengandung ejekan secara langsung, tidak memerintah secara langsung, serta menghormati orang lain.

Oleh karena itu, kesantunan berbahasa ini perlu dikaji guna mengetahui seberapa banyak kesalahan atau penyimpangan kesantunan berbahasa pada manusia ketika berkomunikasi satu sama lain. Permasalahan yang ditemukan pada siswa di sekolah dalam keterampilan berbicara salah satunya adalah diskusi. Kegiatan berdiskusi merupakan suatu upaya untuk mengungkapkan gagasan, ide, dan pendapat mengenai suatu masalah yang menjadi topik diskusi. Dalam kegiatan pembelajaran yang menggunakan metode diskusi terkadang muncul penggunaan bahasa-bahasa yang kurang santun pada siswa dalam mengemukakan pendapatnya. Oleh sebab itu, dalam kegiatan pembelajaran diperlukan materi cara berdiskusi yang santun dan pilihan kata yang tepat ketika berbicara kepada orang lain.

\section{METODE}

Desain penelitian ini adalah desain deskriptif-kualitatif. Penulis hanya mendeskripsikan atau menggambarkan pemanfaatan prinsip kesantunan berbahasa dalam kegiatan diskusi di kelas VII SMP Negeri 1 Pancarijang. Data penelitian berupa kata-kata atau pernyataan dalam bentuk penjelasan dengan kata-kata atau tulisan. Sumber data diambil dari siswa/siswi kelas VII.4 SMP Negeri 1 Pancarijang.

Data dikumpulkan menggunakan teknik simak, teknik catat, dan teknik rekam. Data dianalisis dengan menggunakan metode padan pragmatik. Penggunaan metode padan pragmatik ini didasarkan pada asumsi bahwa bahasa yang diteliti memiliki hubungan dengan unsur-unsur yang berada di luar bahasa yang bersangkutan. Analisis data dilakukan dengan memahami setiap peristiwa berbahasa, memilih dan mengklasifikasikan data berdasarkan penyimpangan maksim kesantunan.

\section{HASIL DAN PEMBAHASAN Hasil Penelitian}

Hasil penelitian berupa data tentang penyimpangan prinsip kesantunan berbahasa prinsip kesantunan berbahasa.

Tabel 1 Penyimpangan Prinsip Kesantunan Berbahasa pada Kegiatan Diskusi Kelas Siswa Kelas VII SMP Negeri 1 Panca Rijang

\begin{tabular}{ccccccc}
\hline \multirow{2}{*}{ Topik } & \multicolumn{7}{c}{ Penyimpangan } \\
\cline { 2 - 7 } & A & B & C & D & E & F \\
\hline 1 & - & 1 & 1 & - & - & - \\
\hline 2 & - & - & 1 & 1 & - & - \\
\hline 3 & 1 & - & 1 & - & 1 & 1 \\
\hline 4 & 1 & - & 1 & 1 & - & - \\
\hline Jumlah & 2 & 1 & 4 & 2 & 1 & 1 \\
\hline Total & \multicolumn{7}{c}{11} & & \\
\hline
\end{tabular}

Keterangan:

$\underline{\text { Topik }}$

1. Pengaruh Teknologi

2. Kenakalan Remaja

3. Handphone dan Anak-Anak

4. Kebersuhan Lingkungan

Maksim

A. Maksim Kebijaksanaan

B. Maksim Kedermawanan

C. Maksim Penghargaan

D. Maksim Kesederhanaan

E. Maksim Pemufakatan

F. Maksim Kesimpatian

Tabel 1 menunjukkan 11 tuturan yang menyimpang, sebagian besar maksim yang banyak dilanggar adalah maksim penghargaan yang berjumlah 4 tuturan. Dari data di atas menunjukkan bahwa dari ke empat topik yang didiskusikan oleh siswa kelas VII SMP Negeri 1 Pancarijang, penyimpangan prinsip kesantunan berbahasa paling banyak muncul pada handphone dan anak-anak

\section{PEMBAHASAN}

Pembahasan ini membahas tentang bentuk-bentuk penyimpangan dan kepatuhan prinsip berbahasa pada kegiatan diskusi. 


\section{Penyimpangan Prinsip Kesantunan Berbahasa pada Kegiatan Diskusi Kelas Siswa Kelas XI SMA N 1 Sleman}

Deskripsi penyimpangan prinsip kesantunan akan dijabarkan berdasarkan maksim-maksim yang dilanggar.

\section{a. Maksim Kebijaksanaan}

Maksim kebijaksanaan dalam prinsip kesantunan adalah bahwa para peserta pertuturan hendaknya berpegang pada prinsip untuk selalu mengurangi keuntungan dirinya sendiri dan memaksimalkan keuntungan pihak lain dalam kegiatan bertutur (Rahardi, 2005) . Penyimpangan maksim kebijaksanaan dalm kegiatan diskusi ini ditandai dengan pemilihan kosakata yang kasar dalam bertanya, berpendapat, dan menyanggah pendapat orang lain, memaksakan pendapat dan menyindir peserta lain sehingga dapat meminimalkan keuntungan pada orang lain. Penyimpangan maksim kebijaksanaan dapat dilihat pada data berikut.

(1) Moderator : "Manfaat dari handphone itu cukup banyak ya. Misalnya, dengan adanya handphone, kita dapa dengan mudah berkomunikasi dengan orang yang jauh, dapat membantu kita dalam meyelesaikn tugas. Sudah cukup kan, ya?"

$$
\text { : "Iya". }
$$

(Data kelompok 3)

Konteks:

Ketika moderator menjawab sendiri pertanyaan dari penanya, moderator memaksakan pendapatnya pada penanya agar penanya setuju dengan jawaban penyaji.

Penyimpangan maksim kebijaksanaan terdapat pada data (1) karena tuturan moderator terlihat mengurangi keuntungan pada pihak penanya. Tuturan penyaji menyimpang dari prinsip kesantunan karena dalam tuturan Sudah cukup kan ya? terlihat moderator memaksakan jawabannya sehingga penanya terpaksa menyudahi pertanyaannya. Di dalam skala keuntungan-kerugian, suatu tuturan akan menjadi tidak santun jika semakin mengurangi keuntungan pada lawan tutur.

(2) Penyaji : "Membakar sampah. Sudah cukup kan, ya?"

Penanya (k.3) : "OOhh iya, sudah cukup."

(Data kelompok 4)

Konteks:

Ketika penyaji menjawab pertanyaan dari penanya, memaksakan pendapatnya pada penanya agar penanya setuju dengan jawaban penyaji.

$$
\text { Penyimpangan maksim }
$$

kebijaksanaan terdapat pada data (2) karena tuturan moderator terlihat mengurangi keuntungan pada pihak penanya. Tuturan penyaji menyimpang dari prinsip kesantunan karena dalam tuturan Sudah cukup kan ya? terlihat moderator memaksakan jawabannya sehingga penanya terpaksa menyudahi pertanyaannya. Di dalam skala keuntungankerugian, suatu tuturan akan menjadi tidak santun jika semakin mengurangi keuntungan pada lawan tutur.

\section{b. Maksim Penghargaan}

Maksim penghargaan diutarakan dengan kalimat ekspresif dan kalimat asertif (Wijana, 1996). Contoh tuturan ekspresif yakni mengucapkan selamat, mengucapkan terima kasih, memuji, dan mengungkapkan bela sungkawa. Dalam maksim ini menuntut setiap peserta pertuturan untuk memaksimalkan rasa hormat kepada orang lain, dan meminimalkan rasa tidak hormat kepada orang lain. Maksim penghargaan menuntut setiap peserta pertuturan untuk memaksimalkan rasa hormat kepada orang lain, dan meminimalkan rasa tidak hormat pada diri sendiri. Tuturan dikatakan santun jika dapat memberi penghargaan untuk orang lain sehingga orang lain akan merasa senang. Penyimpangan dalam maksim ini ditandai dengan adanya sikap tidak mau menghargai pendapat orang lain, memberikan kritik yang menjatuhkan orang lain, dan berbicara yang merendahkan orang lain. Contoh penyimpangan maksim penghargaan dijabarkan sebagai berikut.

(3) Moderator : "Selanjutnya, saya persilahkan kepada kelompok 4 untuk mengajukan pertanyaan." 
Pesesrta (k.4) :

"Tidak tahu.

Hehehe..."

Konteks:

(Data kelompok 1)

Pada saat moderator mempersilahkan peserta kelompok 4 untuk mengajukan pertanyaan, peserta kelompok 4 justru tertawa.

Data (3) di atas menyimpang dari maksim penghargaan karena tuturan peserta diskusi terasa tidak menghormati dan tidak menghargai moderator. Tuturan pada data (3) menjadi tidak santun karena tuturan pihak peserta (k.4) yakni Tidak tahu. Hehehe terasa tidak menghargai orang lain yang akan berbicara, bahkan terkesan merendahkan orang lain sehingga tuturan tersebut dapat menyakiti hati orang lain.

(4) Penyaji : "Pergaulan bebas sendiri berasal dari eksploitasi seksual yang dialami oleh remaja. Eksploitasi seksual umumnya terdapat pada gambar-gambar dan video yang tidak senonoh yang marak beredar".

Peserta : "Ahh salah. Hahaha ...”

(Data kelompok 2)

Konteks:

Pada saat penyaji menjawab pertanyaan dari penanya, peserta diskusi tiba-tiba menanggapi tanpa memberikan alasan bahwa jawaban dari penyaji itu salah.

Data (4) di atas menyimpang dari maksim penghargaan karena tuturan peserta terasa tidak menghargai jawaban dari penyaji. Tuturan pada data (4) menjadi tidak santun karena pihak peserta yakni $\boldsymbol{A h h}$ salah. Hahaha terasa tidak menghargai jawaban dari orang lain, bahkan terkesan merendahkan orang lain sehingga tuturan tersebut dapat menyakiti dan menyinggung perasaan orang lain.

(5) Moderator : "Ya, untuk pertanyaan dari perwakilan kelompok 4 akan saya jawab sendiri."

Peserta : "Hahaha, gayamu..." (Data kelompok 3)

Konteks:

Pada saat moderator mau menjawab pertanyaan dari peserta, ada siswa yang meledek moderator.

Data (5) di atas menyimpang dari maksim penghargaan karena tuturan peserta diskusi terasa tidak menghormati penyaji. Tuturan pada data (5) menjadi tidak santun karena tuturan pihak penanya yakni Hahaha, gayamu terasa tidak menghargai orang lain yang akan berbicara, bahkan terkesan merendahkan orang lain sehingga tuturan tersebut dapat menyakiti hati orang lain.

(6) Penanya (k.1) : "Hoiii. Apa pengertian lingkungan?"

Penyaji : "Kebersihan adalah salah satu sumber daya alam yang sangat besar artinya bagi makhluk hidup."

(Data kelompok 4)

Konteks:

Pada saat berdiskusi, penanya mengajukan pertnyaannya dengan seoaholah berteriak kepada penyaji. Namun, penyaji tetap menghargai pertanyaan dari penanya lalu menjawabnya.

Data (6) di atas menyimpang dari maksim penghargaan karena tuturan penanya (k.1) terasa tidak menghormati penyaji. Tuturan pada data (6) menjadi tidak santun karena pihak penanya yakni Hoiii, apa pengertian lingkungan? Terdengar meneriaki penanya dalam mengungkapkan pertanyaan sehingga hal tersebut terasa tidak santun dalam berbicara. Dalam maksim penghargaan ini orang akan dianggap santun apabila dalam bertutur selalu berusaha memberikan penghargaan pada orang lain.

\section{c. Maksim Kedermawanan}

Prinsip maksim kedermawanan ini adalah buatlah keuntungan diri sendiri sekecil mungkin; buatlah kerugian diri sendiri sebesar mungkin (Leech, 1993). Maksim kedermawanan disebut juga maksim kemurahan hati. para peserta pertuturan diharapkan dapat menghormati orang lain (Rahardi, 2005). Maksim kedermawanan ini menuntut peserta pertuturan untuk membuat keuntungan pada diri sendiri sekecil mungkin, dan membuat kerugian pada diri sendiri sebanyak mungkin. Tuturan akan menjadi santun, jika penutur mampu menghormati orang lain dengan cara memaksimalkan keuntungan pada lawan tuturnya. Penyimpangan dalam maksim ini ditandai dengan adanya sikap tidak mau memberikan kesempatan pada orang lain untuk berpendapat, dan memberikan perintah atau menolak pendapat 
peserta lain tidak menggunakan kalimat pertanyaan. Data yang termasuk dalam penyimpangan maksim kedermawanan diuraikan sebagai berikut.

\section{(7) Penyaji : "Gak jelas. Ayo di ulang lagi! " \\ Penanya (k.2) \\ "Pertanyaanku, apa dampak positif dari teknologi?"}

\section{(Data kelompok1)}

Konteks:

Pada saat penyaji tidak mendengarkan pertnyaan dengan jelas, penanya (k.2) pun mengulang kembali pertanyaannya.

Data (7) menyimpang dari maksim kedermawanan karena tuturan penyaji menunjukkan sikap tidak mampu menghormati orang lain. Tuturan gak jelas, ayo diulang lagi! terasa tidak santun karena peserta memerintah orang lain tidak menggunakan kalimat pertanyaan atau diksi yang lebih halus. Kata "ayo" akan menjadi lebih santun jika diganti dengan kata "tolong" atau "mohon". Jadi pada tuturan di atas, lebih memaksimalkan keuntungan pada diri sendiri.

\section{d. Maksim Kesederhanaan}

Maksim kesederhanaan disebut juga peserta tutur diharapkan dapat bersikap rendah hati dengan cara mengurangi pujian terhadap dirinya sendiri (Rahardi, 2005). Pada maksim ini peserta pertuturan diharapkan dapat bersikap rendah hati, mengurangi pujian terhadap diri sendiri dan memaksimalkan kehormatan pada orang lain. Penyimpangan dalam maksim ini ditandai dengan sikap penutur yang berprasangka buruk terhadap lawan tutur dan penutur yang menonjolkan kelebihannya di depan orang lain. Data yang termasuk dalam penyimpangan maksim kesederhanaan dijabarkan di bawah ini.

(8) Penyaji : "Dapat menghilangkan stress."

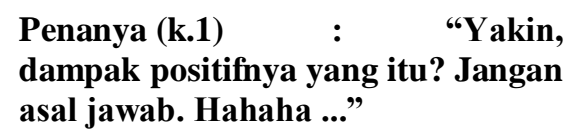

(Data kelompok 2)

Konteks:
Pada saat diskusi, penanya (k.1) bertanya kembali kepada penyaji yang pertanyaannya memojokkan penyaji.

Data (8) menyimpang dari maksim kesederhanaan, karena tuturan penanya memaksimalkan kehormatan pada diri sendiri. Tuturan penanya Yakin, dampak positifnya yang itu? Jangan asal jawab. Hahaha. meminimalkan kehormatan pada orang lain, karena pihak penanya terlihat berprasangka buruk kepada penyaji yang bisa membuat penyaji merasa terpojok.

(9) Penanya (k.1) : "Apa pengertian kebersihan?"

Penyaji : Kebersihan adalah keadaan bebas dari sampah termasuk diantaranya debu dan bau. Heee apalagi?

\section{(Data kelompok 4)}

Konteks:

Penyaji menjawab pertanyaan dari penanya dengan kata-kata yang menunjukkan kesombongannya.

Data (9) menyimpang dari maksim kesederhanaan karena tuturan penyaji di atas tidak mengurangi pujian terhadap dirinya sendiri. Pada kalimat Heee apalagi? menunjukkan bahwa penyaji memamerkan kelebihannya dengan seolah-olah meminta penanya untuk bertanya lagi. Dalam tuturan di atas terlihat bahwa penyaji tidak mampu bersikap rendah hati dan tidak mampu mengurangi pujian untuk dirinya sendiri.

\section{e. Maksim Permufakatan}

Maksim ini menekankan agar para peserta tutur dapat saling membina kecocokan atau kemufakatan di dalam kegiatan bertutur (Rahardi, 2005). Dalam maksim permufakatan peserta tutur ditekankan dapat saling membina kecocokan atau kemufakatan di dalam kegiatan bertutur. Tuturan dikatakan santun jika antara penutur dan lawan tutur bisa memaksimalkan kecocokan di antara mereka. Penyimpangan maksim permufakatan dalam diskusi kelas ditandai dengan sikap peserta diskusi yang tidak mau mendukung pendapat yang benar meskipun pendapatnya salah, para peserta tidak mampu berbicara sesuai pokok permasalahan, dan para peserta tidak mau menerima atau menyetujui hasil diskusi. 
Berikut adalah data penyimpangan pada maksim permufakatan.

(10)Peserta : "Bukannya dengan hadirnya handphone itu justru mendekatkn kita pada dunia kita sendiri. Bukannya menjauhi. Karena dengan adanya handphone dapat menambah pengetahuan anak."

Penyaji : "Maksud dari pernyataan saya sebelumnya yaitu bahwa adanya handphone mereka akan semakin menjauh dari dunia mereka. Misalnya biasanya anakanak akan menjadi lebih malas belajar. Yaa seperti itu."

(Data kelompok 3)

Konteks:

Pada saat penyaji menjawab pertanyaan dari penanya, peserta diskusi justru tidak sependapat dengan jawaban yang diberikan oleh penyaji, sementara itu penyaji memberikan penjelasan untuk menguatkan pendapatnya.

Data (10) menyimpang dari maksim permufakatan karena penyaji tidak mampu membina kecocokan dengan peserta. Dari tuturan penyaji di atas menunjukkan bahwa penyaji tidak mau mendukung pendapat yang benar, meskipun pendapatnya salah. Penyaji tetap memberikan pembelaan untuk menguatkan pendapatnya, walaupun jawabannya kurang didukung bukti yang kuat. Oleh karena itu, tuturan di atas dikatakan tidak santun karena penyaji tidak mampu memaksimalkan kecocokan dengan peserta

\section{f. Maksim Kesimpatian}

Maksim ini mengharapkan agar para peserta tutur dapat memaksimalkan sikap simpati antara pihak yang satu dengan pihak lainnya (Leech, 1993). Dalam maksim kesimpatian ini diharapkan peserta tutur dapat memaksimalkan sikap simpati kepada orang lain. Tuturan akan terasa santun jika seseorang dapat menunjukkan sikap simpatinya dan tidak bersikap sinis terhadap orang lain. Penyimpangan pada maksim ini ditandai dengan sikap penutur yang tidak mau memberikan dukungan yang tulus pada orang lain yang pendapatnya benar, dan tidak memberikan sikap simpati pada orang lain yang salah. Berikut adalah data penyimpangan pada maksim kesimpatian.

(11) Moderator : "Selamat siang temanteman. Kami dari kelompok 3 akan mempersentasikan materi kami tentang Handphone. Maaf saya ulangi."

Peserta : "Huuu..."

(Data kelompok 3)

Konteks:

Pada saat moderator membuka presentasi, moderator melakukan kesalahan dalam penyampaian judul, kemudian peserta menyoraki moderator.

Tuturan pada data (11) menyimpang dari maksim kesimpatian karena peserta diskusi tidak memberikan rasa simpati kepada moderator yang melakukan kesalahan dalam menyampaikan judul. Tuturan peserta menunjukkan sikap mengejek dan sinis terhadap kesalahan yang dilakukan lawan tuturnya. Orang yang tidak mampu memberikan rasa simpati yang tulus pada orang lain yang berbuat salah disebut sebagai orang yang tidak tahu sopan santun di dalam masyarakat.

\section{PENUTUP}

Kesimpulan penelitian ini adalah bentuk penyimpangan prinsip kesantunan pada kegiatan diskusi siswa kelas VII SMP Negeri 1 Panca Rijang berupa penyimpangan maksim seperti penyimpangan maksim kebijaksanaan, maksim penghargaan, maksim kedermawanan, maksim kesederhanaan, maksim permufaatan dan maksim kesimpatian. Di antara maksim-maksim tersebut, maksim yang paling banyak disimpangkan adalah maksim penghargaan. Berdasarkan topik yang didiskusikan, penyimpangan prinsip kesantunan berbahasa paling banyak muncul pada topik handphone dan anak-anak, dan kebersihan lingkungan. Oleh karena itu, disarankan agar penerapan prinsip kesantunan berbahasa perlu ditingkatkan, baik dalam kehidupan di sekolah maupun di masyarakat karena akan berpengaruh dengan perkembangan kebahasaan dan tingkah laku anak. 


\section{DAFTAR PUSTAKA}

Chaer, A., \& Agustina, L. 2004. Sosiolinguistik Perkenalan Awal. Jakarta: Rineka Cipta.

Kridalaksana. 1993. Kamus Linguistik. Jakarta: Ggramedia Pustaka.

Leech, G. 1993. The Principle of Pragmatics. Jakarta: Universitas Indonesia Press.
Rahardi, K. 2005. Pragmatik Kesantunan Imperatif Bahasa Indonesia. Jakarta: Erlangga.

Wijana, I. D. 1996. Dasar-dasar Pragmatik. Yogyakarta: Andi. 